\title{
ANALISIS KEUNGGULAN KOMPARATIF KOMODITAS INDUSTRI PERTAHANAN INDONESIA TERHADAP ASEAN 4 DAN CHINA
}

\author{
Nurul Azizah Az zakiyyah \\ Universitas Ahmad Dahlan \\ nurulazizahazzakiyyah@gmail.com
}

\begin{abstract}
This study analyzes the comparative advantages of Indonesia's defense industry products against ASEAN-4 and China in the context of the ADIC (ASEAN Defense Industry Collaboration) collaboration. The data used is data from 10 defense industry products taken from UN COMTRADE using the 4 digit HS classification so that 248 commodities were analyzed. The measure of comparative advantage used is the Revealed Symmetric Comparative Advantage (RSCA), while to determine whether the country is a net-importer or net-exporter, the Trade Balance Index (TBI) is used. Finally, the authors combine the two indices of comparative advantage to draw a mapping of Indonesia's defense industry products for each ASEAN-4 country and China. The analysis shows that most of Indonesia's export commodities (net-exporters) and comparative advantage are still primary products. While some products that have advantages over one country are primary cells and primary batteries and electrical materials (8506), roter or spark-ignition internal combustion piston engines (8407), vending machines for goods (postage, food or beverage) including exchange machines. money (8476), Tubes, pipes and hollow profiles of cast iron (7303).
\end{abstract}

Kata kunci : ASEAN, China, TBI, Product Mapping

\section{LATAR BELAKANG}

Lebih dari satu dekade yang lalu tepatnya setelah krisis yang melanda negaranegara Asia Tenggara, masing-masing kepala negara Asia Tenggara menyepakati pembentukan Komunitas ASEAN (ASEAN Community) dalam bidang Ekonomi (ASEAN Economic Community), Sosial dan Budaya (ASEAN Socio-culture Economic) serta Keamanan Politik (ASEAN PoliticalSecurity Community). Dari kesepakatan tersebut salah satu komunitas ASEAN yang telah disepakati adalah integrasi di bidang ekonomi yang dibentuk untuk menghadapi perdagangan bebas di antara negara-negara ASEAN. Integrasi ekonomi ini dilakukan dalam rangka meningkatkan daya saing negara-negara ASEAN serta untuk bersaing dengan China sebagai negara saingan ASEAN dalam menarik investasi asing.

Pada tahun 2011 integrasi komunitas ASEAN memulai kerja sama di bidang pertahanan dan keamanan regional. Hal ini dimulai melalui adanya kesepakatan pembentukan kolaborasi industri pertahanan ASEAN atau ASEAN Defense Industry Collaboration (ADIC). Kesepakatan kolaborasi tersebut disetujui oleh empat negara ASEAN yaitu Malaysia, Indonesia, Singapura dan Thailand. Tujuannya adalah untuk mengurangi tingkat impor kebutuhan alat pertahanan negara-negara anggota ASEAN dari negara Amerika Serikat. Besarnya tingkat impor negara ASEAN sendiri disebabkan rendahnya kemampuan negara-negara ASEAN dalam memproduksi alat pertahanan dimana tidak seimbang dengan besarnya kebutuhan alat pertahanan negara-negara tersebut (Wijaya, 2015).

Dalam dokumen kesepakatan ADIC terdapat beberapa kegiatan yang terangkum dalam empat kelompok yaitu (1) pendidikan dan pelatihan di sektor industri pertahanan; (2) partnership, jointventures, dan coproduction program-program industri 
pertahanan; (3) penelitian dan pengembangan bersama program-program industri pertahanan atau co-development; dan (4) promosi bersama dalam pengembangan program industri pertahanan. Dari keempat bentuk kegiatan yang disepakati, dapat dilihat bahwa terdapat bentuk yang dikenal dengan istilah reciprocal trade, di mana negara-negara yang berkolaborasi sepakat untuk saling membeli alat pertahanan yang diproduksi oleh salah satu anggota kolaborasi (Ningsih, 2019). Kesepakatan ini dapat diasumsikan juga sebagai bagian dari integrasi ekonomi yang telah berjalan sebelumnya.

Dari 10 negara ASEAN hanya dua negara (Indonesia dan Singapura) yang dianggap memiliki industri pertahanan yang cukup signifikan. Meskipun demikian jenis alat pertahanan yang dapat diproduksi kedua negara masih sangat terbatas (Raghavan dan Ben-Ari, 2011). Indonesia memiliki potensi dalam mengembangkan industri pertahanan yang kuat. Pembangunan pertahanan dan keamanan memiliki arti yang sangat penting dalam menuntaskan pencapaian sasaran pembangunan nasional dan pelaksanaan agenda demokrasi. Alokasi anggaran belanja pemerintah untuk fungsi pertahanan dimana di dalamnya terdapat pos penggunaan anggaran untuk peningkatan industri pertahanan menunjukkan kecenderungan naik meskipun nilainya tidak signifikan.

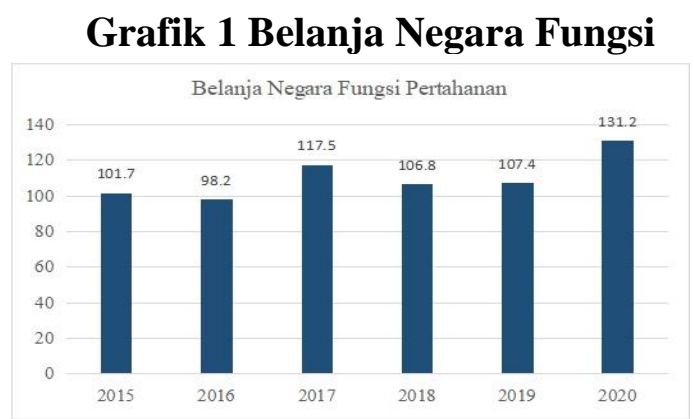

Sumber : Nota Keuangan (2020)

Saat ini setidaknya terdapat 10 BUMN yang berkaitan dengan industri pertahanan yang sedang dikembangkan oleh pemerintah, 10 BUMN tersebut adalah PT Dirgantara Indonesia, PT PAL Indonesia, PT Pindad, PT Dahana , PT Krakatau Steel, PT Barata Indonesia, PT Boma Bisma Indra, PT Kereta Api, PT Telekomunikasi Indonesia, dan PT LEN. Kesepuluh industri strategis tersebut memiliki peluang besar untuk dikembangkan menjadi pusat unggulan yang dapat mendukung industri pertahanan indonesia.

Dalam usaha memajukan industri pertahanan, Indonesia tentu menghadapi tantangan yang sangat kompleks baik berupa persaingan ketat antar negara dalam merebut pangsa pasar maupun kemampuan memproduksi dan daya saing industri pertahanan itu sendiri. Jika Industri pertahanan Indonesia memiliki daya saing yag tinggi terhadap negara lain maka industri ini dapat memberikan efek pertumbuhan ekonomi dan menggairahkan industri nasional sehingga mampu mencapai skala internasional, penyerapan tenaga kerja dalam jumlah yang cukup signifikan, transfer teknologi yang dapat menggairahkan sektor penelitian dan pengembangan, sekaligus memenuhi kebutuhan sektor pendidikan nasional di bidang sains dan teknologi

Berdasarkan latar belakang yang telah dijelaskan diatas maka penulis tertarik untuk melakukan penelitian dengan judul : "Analisis Keunggulan Komparatif Komoditas Industri Pertahanan Indonesia terhadap ASEAN 4 dan China”.

\begin{tabular}{l}
\hline LANDASAN TEORI \\
\hline Teori Keunggulan Komparatif \\
David Ricardo memperkenalkan \\
konsep yang disebut teori keunggulan \\
komparatif. Teori keunggulan komparatif \\
oleh David Ricardo ini merupakan kritik \\
terhadap teori keunggulan absolut yang \\
dikemukakan oleh Adam Smith yang
\end{tabular}


berpendapat bahwa perdagangan internasional hanya akan terjadi jika ada perbedaan antara keunggulan absolut di kedua negara. Ricardo berpendapat bahwa perdagangan internasional tidak selalu terjadi karena perbedaan dalam keunggulan absolut, tetapi juga karena keunggulan komparatifnya. Ricardo (1987) dalam Widodo (2009) menyatakan bahwa prinsip keunggulan komparatif menyatakan bahwa suatu negara akan mengekspor barang atau jasa di mana mereka memiliki keunggulan komparatif terbesar dan mengimpor barang dan jasa yang memiliki keunggulan komparatif rendah.

\section{Teori Heckser-Ohlin (HO)}

Teori ini adalah pengembangan teori keunggulan komparatif David Ricardo yang didasarkan pada kepemilikan faktor produksi. Menurut Salvatore (2007) dalam Shahibul (2013), teori HO didasarkan pada asumsi, (1) ada dua negara (negara 1 dan 2), dua komoditas ( $\mathrm{X}$ dan $\mathrm{Y}$ ), dan dua faktor produksi (tenaga kerja dan modal) ), (2) skala pengembalian konstan dan teknologi mirip, (3) komoditas X padat karya dan komoditas Y padat modal, (4) dua komoditas diproduksi dalam skala pengembalian konstan untuk kedua negara, (5) ada spesialisasi yang tidak lengkap dalam produksi untuk kedua negara, (6) faktor produksi benar-benar tidak bergerak melintasi perbatasan internasional tetapi dapat bergerak tanpa biaya di antara industri di dalam negeri (7) barang dan faktor yang sama, dan selera untuk kedua negara, (8) tidak ada biaya transportasi, tarif, atau hambatan lain terhadap aliran perdagangan internasional, (9) semua sumber daya dipekerjakan sepenuhnya di kedua negara, dan (10) perdagangan internasional antara kedua negara seimbang.

Dalam Teori H-O, suatu negara akan mengekspor komoditas yang diproduksi oleh faktor produksi yang murah dan berlimpah, dan akan mengimpor komoditas yang faktor produksinya relatif lebih langka dan mahal di dalam negeri.

\section{Teori Akamatsu Flying Geese}

Pada tahun 1961, Akamatsu menerbitkan model yang disebut model Flying Geese (FG). Model ini menunjukkan bagaimana proses negara-negara berkembang mengejar ketinggalan industrialisasi terhadap negara-negara maju. Menurut Kojima (2000) dalam Shahibul (2013), model FG terdiri dari empat fase: (1) negara berkembang mengimpor barangbarang konsumen dari negara maju, (2) memulai produksi di negara tersebut dan mulai mengimpor barang modal dari negara maju atau yang disebut substitusi impor, (3) Penurunan impor barang konsumen dan persiapan untuk ekspor, (4) negara-negara berkembang mulai mengekspor barang modal seiring dengan penurunan ekspor barang konsumsi.

\section{Product Mapping}

Widodo (2009) berpendapat bahwa ada dua sudut pandang untuk menjelaskan produk-produk leading export. Pertama, dari sudut pandang domestik, produk-produk leading export dimaksudkan sebagai produk ekspor yang dapat memberikan jumlah devisa yang lebih besar untuk ekonomi domestik. Kedua, dari sudut pandang persaingan internasional, produk-produk leading export adalah produk yang memiliki keunggulan komparatif di pasar internasional. Kedua sudut pandang yang dinyatakan di atas, digabungkan dalam suatu alat analisis, yaitu "Product Mapping". Revealed Symmetric Comparative Advantage (RSCA) digunakan sebagai Indikator yang neraca perdagangan domestik sementara indikator untuk mewakili daya saing internasional (kegiatan ekspor-impor) adalah Trade Balance Index (TBI).

\begin{tabular}{|c|c|c|c|}
\hline \multicolumn{4}{|c|}{ Tabel 3.1. Studi Literatur } \\
\hline \begin{tabular}{|c|} 
Nama dan \\
Judul \\
Penelitian \\
\end{tabular} & Metode Penelitian & Temuan & Perbandingan \\
\hline $\begin{array}{l}\text { Widodo, } \\
\text { Tri. } \\
(2009) .\end{array}$ & $\begin{array}{l}\text { Data yang digunakan } \\
\text { adalah data ekspor } \\
\text { SITC Rev.2 } 3 \text { digit } \\
\text { yang berasal dari UN }\end{array}$ & $\begin{array}{l}\text { Hasil penelitian } \\
\text { menunjukkan } \\
\text { bahwa semakin } \\
\text { tinggi }\end{array}$ & $\begin{array}{l}\text { Hasil dari } \\
\text { penelitian ini } \\
\text { dijadikan } \\
\text { sebagai acuan }\end{array}$ \\
\hline Comparati & COMTRADE & $\begin{array}{l}\text { keunggulan } \\
\text { komparatif }\end{array}$ & $\begin{array}{l}\text { untuk } \\
\text { menganalisis }\end{array}$ \\
\hline
\end{tabular}




\begin{tabular}{|c|c|c|c|}
\hline $\begin{array}{l}\text { ve } \\
\text { advantage } \\
\text { : theory, } \\
\text { empirical } \\
\text { measures, } \\
\text { and case } \\
\text { studies }\end{array}$ & $\begin{array}{l}\text { Alat Analisis } \\
\text { menggunakan } \\
\text { Revealed Symetric } \\
\text { Comparative } \\
\text { Statistic (RSCA) dan } \\
\text { Trade Balance Index } \\
\text { sehingga } \\
\text { menghasilkan } \\
\text { Product Mapping }\end{array}$ & $\begin{array}{l}\text { untuk produk } \\
\text { tertentu, } \\
\text { semakin besar } \\
\text { kesempatan } \\
\text { negara untuk } \\
\text { menjadi net } \\
\text { eksportir }\end{array}$ & $\begin{array}{l}\text { product } \\
\text { mapping khusus } \\
\text { di Industri } \\
\text { pertahanan. }\end{array}$ \\
\hline $\begin{array}{l}\text { Wijaya, } \\
\text { Dicky } \\
\text { Hadi } \\
(2015) \\
\\
\text { Kolaboras } \\
\text { i Industri } \\
\text { Pertahana } \\
\text { n ASEAN } \\
\text { (ADIC) } \\
\text { ditinjau } \\
\text { dari } \\
\text { keunggula } \\
n \\
\text { Komparati } \\
\text { f Dengan } 3 \\
\text { Negara } \\
\text { Anggota: } \\
\text { Malaysia, } \\
\text { Singapura, } \\
\text { Thailand }\end{array}$ & $\begin{array}{l}\text { Data Ekspor produk } \\
\text { industri pertahanan } \\
\text { 2010-2013 dari } 10 \\
\text { komoditi Indonesia } \\
\text { dan } 3 \text { Negara Asean } \\
\text { Alat analisis } \\
\text { Revealed } \\
\text { Comparative } \\
\text { Advantage (RCA) }\end{array}$ & \begin{tabular}{|l|} 
Indonesia \\
memiliki \\
keunggulan \\
komparatif \\
untuk jenis \\
komoditi ship, \\
boat dan \\
floating \\
structure \\
terhadap \\
Malaysia dan \\
Singapura. \\
Sementara \\
terhadap \\
Thailand \\
indonesia \\
memiliki \\
keunggulan \\
untuk komoditas \\
copper dan \\
article thereof
\end{tabular} & $\begin{array}{l}\text { Hasil penelitian } \\
\text { ini dijadikan } \\
\text { acuan dengan } \\
\text { menambahkan } \\
\text { filipina dan } \\
\text { China kedalam } \\
\text { Object } \\
\text { Penelitian serta } \\
\text { menggunakan } \\
\text { alat analisis } \\
\text { yang berbed } \\
\text { yaitu RSCA, } \\
\text { TBI dan Product } \\
\text { Mapping }\end{array}$ \\
\hline $\begin{array}{l}\text { Shohibul } \\
(2013) \\
\text { Revealed } \\
\text { comparati } \\
\text { ve } \\
\text { advantage } \\
\text { measure: } \\
\text { ASEAN- } \\
\text { China } \\
\text { trade } \\
\text { flows }\end{array}$ & \begin{tabular}{|l} 
Produk ekspor \\
dianalisis \\
berdasarkan \\
klasifikasi SITC rev \\
3, yang dibagi \\
menjadi produk \\
primer dan produk \\
manufaktur \\
Alat Analisis \\
menggunakan \\
Revealed Symmetric \\
Comparative \\
Advantage (RSCA) \\
dan Trade Balance \\
Index (TBI)
\end{tabular} & $\begin{array}{l}\text { Hasil penelitian } \\
\text { menunjukkan } \\
\text { bahwa China } \\
\text { memiliki pola } \\
\text { perdagangan } \\
\text { yang lebih } \\
\text { mapan, } \\
\text { sementara pola } \\
\text { perdagangan } \\
\text { ASEAN sangat } \\
\text { dinamis. }\end{array}$ & \begin{tabular}{|l|} 
Hasil dari \\
penelitian ini \\
dijadikan \\
sebagai acuan \\
untuk \\
menganalisis \\
product \\
mapping khusus \\
di Industri \\
pertahanan
\end{tabular} \\
\hline
\end{tabular}

Sumber: Jurnal Penelitian (diolah)

\section{DATA DAN METODOLOGI}

\section{Data}

Penelitian ini menggunakan data ekspor dan impor negara Indonesia, ASEAN4 dan China periode 2011-2019. Data diambil dari UN COMTRADE yang diakses dari situs International Trade Center. Komoditas yang digunakan dalam penelitian ini berdasarkan sepuluh komoditas ekspor industri pertahanan pada penelitian terdahulu di negara ASEAN 4 dan China di bawah sistem klasifikasi 2 digit Harmonized System (HS). data tersebut kemudian akan diturunkan kembali menjadi klasifikasi HS 4 digit. Berikut data yang akan digunakan dalam penelitian :

Tabel 4.1. Komoditas Industri Pertahanan HS 2 Digit

\begin{tabular}{c|l}
\hline $\begin{array}{c}\text { Kode } \\
\text { HS }\end{array}$ & \multicolumn{1}{|c}{ Komoditas } \\
\hline 72 & Iron and Steel \\
73 & Article of Iron And Steel \\
74 & Copper And Articles Thereof \\
76 & Alumunium And Articles Thereof \\
84 & Nuclear Reactor, Boilers, Machinery and Mechanical \\
& Appliance : Parts Thereof \\
85 & Electrical Machinery and Equipment and Articles \\
& Thereof \\
86 & Railway or Tramway Locomotive and Parts Thereof \\
88 & Aircfraft, Spacecraft, And Parts Thereof \\
89 & Ship, Boats, Floating Structure \\
93 & Arms and Amunition; Parts And Accessories \\
\hline
\end{tabular}

Sumber : International Trade Centre dan US Commercial Service

Karena HS 2 digit pada data 10 produk industri pertahanan tersebut akan di turunkan lagi menjadi klasifikasi HS 4 digit, maka total data yang dianalisis dalam penelitian ini berjumlah 253 komoditas.

\section{METODE ANALISIS}

Analisis data dalam penelitian ini menggunakan pendekatan kuantitatif, dalam penelitian ini akan digunakan alat bantu berupa software statistik yaitu Microsoft Excel.

\section{Revealed Comparative Advantage}

Revealed Comparative Advantage (RCA) adalah cara untuk mengetahui keunggulan komparatif suatu negara. Alat analisis pertama kali dikembangkan oleh Balassa pada tahun 1965 dan didefinisikan sebagai rasio antara produk ekspor tertentu dari keseluruhan ekspor suatu negara terhadap total ekspor dunia (Volrath, 1991), dengan rumusan sebagai berikut :

$$
B_{i j}=\frac{X_{i j} / X_{w j}}{X_{i} / X_{w}}
$$

Source : Balassa dalam Sanidas dan Shin (2010)

$$
\begin{aligned}
& B_{i j}=\text { Balassa index (RCA) Negara i untuk } \\
& \text { komoditas j } \\
& X_{i j}=\text { Ekspor negara i untuk komoditas j }
\end{aligned}
$$


$X_{i}=$ Total ekspor komoditas oleh negara $\mathrm{j}$

$X_{w j}=$ Ekspor dunia untuk komoditas $\mathrm{j}$

$X_{w}=$ Total ekspor komoditas oleh dunia

Justifikasi dari nilai RCA adalah sebagai berikut :

- RCAij $>1$ = Negara i memiliki keunggulan komparatif untuk komoditas $\mathrm{j}$ dibandingkan negara negara lain di dunia atau negara acuan

- RCAij $=1=$ Negara i mendekati kondisi memiliki keunggulan komparatif dibanding negara lain

- RCAij $<1$ = Negara i tidak memiliki keunggulan komparatif untuk komoditas j dibanding negara lain

\section{Revealed Symmetric Comparative Advantage}

Laursen (1998) membuat modifikasi pada indeks RCA Balassa. Hasil modifikasi adalah indeks Revealed Symmetric Comparatie Advantage (RSCA), yang memiliki rentang nilai yang berbeda dengan RCA dan nilainya menjadi lebih simetris, yaitu nilai antara -1 dan +1 .

\section{Indeks RSCA Laursen:}

Jika RSCA lebih besar dari nol maka negara j memiliki keunggulan komparatif dalam produk i, sedangkan jika nilai RSCA kurang dari nol maka negara $\mathrm{j}$ tidak memiliki keunggulan komparatif dalam produk $i$.

\section{Trade Balance Indeks}

Trade Balance Index adalah indeks yang dibuat oleh Lafay (1992) untuk melihat apakah suatu negara mengkhususkan diri dalam ekspor (net eksportir) atau dalam impor (net importir) untuk produk tertentu. Perumusan TBI adalah sebagai berikut:

$$
T B_{i j}=\frac{X_{i j}-M_{i j}}{X_{i j}-M_{i j}}
$$

Sumber: Lafay (1992) dalam Widodo (2009)

$$
\begin{aligned}
& T B_{i j}=\text { Trade Balance Index negara i untuk } \\
& \text { komoditas j }
\end{aligned}
$$

$X_{i j}=$ Ekspor komoditas $\mathrm{j}$ tterhadap dunia oleh negara $\mathrm{i}$
$M_{i j}=$ impor komoditas j dari dunia oleh negara $\mathrm{i}$

Nilai TBI berkisar dari -1 hingga +1 . Nilai TBI -1 menunjukkan bahwa suatu negara hanya mengimpor. Sebaliknya, jika nilai TBI sama dengan +1 itu menunjukkan bahwa suatu negara hanya dapat mengekspor. Sementara itu, jika nilai TBI berkisar antara -1 dan +1 menunjukkan bahwa suatu negara mengekspor dan mengimpor suatu produk secara bersamaan. Suatu negara dikatakan sebagai net importir pada komoditas tertentu ketika TBI bernilai negatif dan dikatakan sebagai net eksportir jika nilainya positif.

\section{Product Mapping}

Pemetaan produk adalah kombinasi antara indeks RSCA dengan TBI oleh Widodo (2009). Komoditas dipetakan ke dalam empat kelompok: A, B, C, dan D. Grup A terdiri dari komoditas yang memiliki keunggulan komparatif dan mengkhususkan diri dalam ekspor. Grup B terdiri dari komoditas yang memiliki keunggulan komparatif tetapi tidak berspesialisasi dalam ekspor. Grup C terdiri dari komoditas yang berspesialisasi dalam ekspor tetapi tidak memiliki keunggulan komparatif. Grup D terdiri dari komoditas yang tidak memiliki keunggulan komparatif dan tidak

\begin{tabular}{|c|c|}
\hline $\begin{array}{c}\text { Group B } \\
\text { Comparative advantage } \\
\text { Net-importer } \\
\text { RSCA }>0>\text { and } \mathrm{TBI}<0\end{array}$ & $\begin{array}{c}\text { Group A } \\
\text { Comparative Advantage } \\
\text { Net-exporter } \\
\text { RSCA }>0 \text { and } \mathrm{TBI}>0\end{array}$ \\
\hline $\begin{array}{c}\text { Group D } \\
\text { Comparative } \\
\text { Disadvantage } \\
\text { Net-importer } \\
\text { RSCA }<\text { 0and TBI }<0\end{array}$ & $\begin{array}{c}\text { Group C } \\
\text { Comparative } \\
\text { Disadvantage } \\
\text { Net-Exporter } \\
\text { RSCA }<0 \text { and TBI }>0\end{array}$ \\
\hline
\end{tabular}
berspesialisasi pada ekspor.

\section{Gambar 4.1 Product Mapping}

Sumber : Widodo (2009) 


\section{HASIL ANALISIS}

\section{Product Mapping}

Product Mapping dihitung dengan menggunakan perhitungan indeks RSCA dan TBI. Seperti yang telah disebutkan sebelumnya, bahwa produk (HS 4) yang dianalisis dalam penelitian ini akan dikategorikan menjadi empat kelompok yaitu A, B, C, dan D seperti yang digambarkan pada Gambar 5.1.

Gambar 5.1 didapatkan dari proses penggabungan nilai grouping RSCA dan TBI, dari penggabungan tersebut diketahui bahwa produk industri pertahanan indonesia terhadap negara ASEAN-4 dan China lebih banyak berada pada kategori D kecuali untuk negara Filipina, hal ini menunjukkan sebagian besar produk industri pertahanan Indonesia tidak memiliki keunggulan komparatif dan tidak berspesialisasi pada ekspor. Khusus untuk Filipina produk industri pertahanan Indonesia lebih banyak tersebar di grup $\mathrm{C}$ yang artinya banyak komoditas dari industri pertahanan yang berspesialisasi ekspor namun tidak memiliki keunggulan komparatif.
Gambar 5.1. Jumlah Produk A, B, C, dan D di Setiap Grup

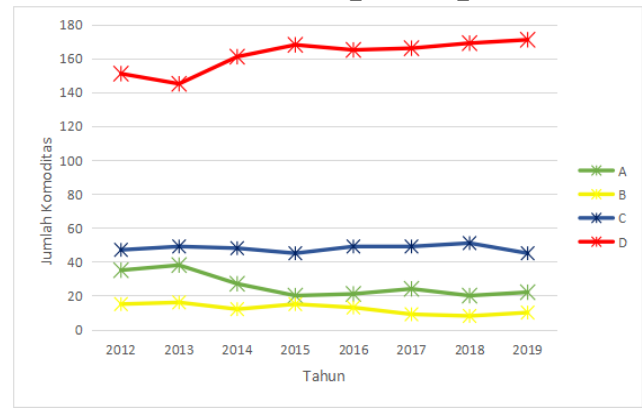

a. Indonesia - Malaysia

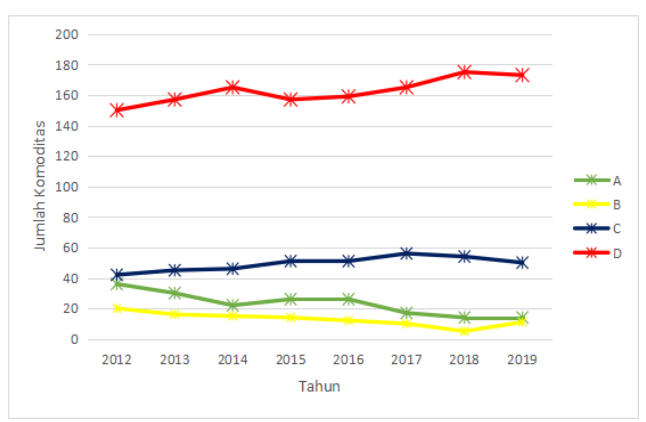

b. Indonesia - Singapura

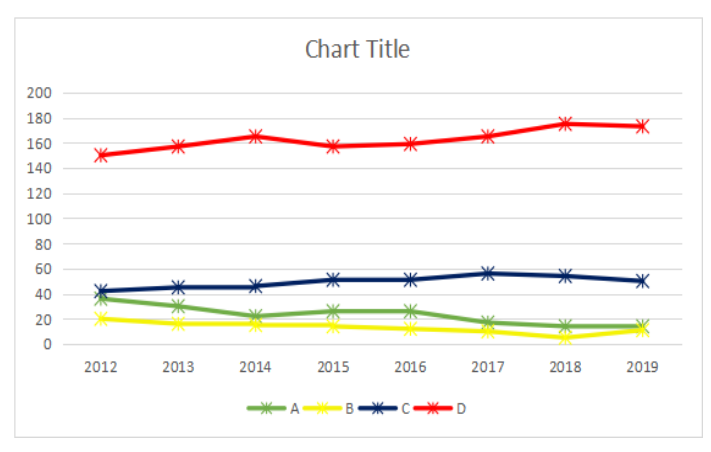

c. Indonesia - China

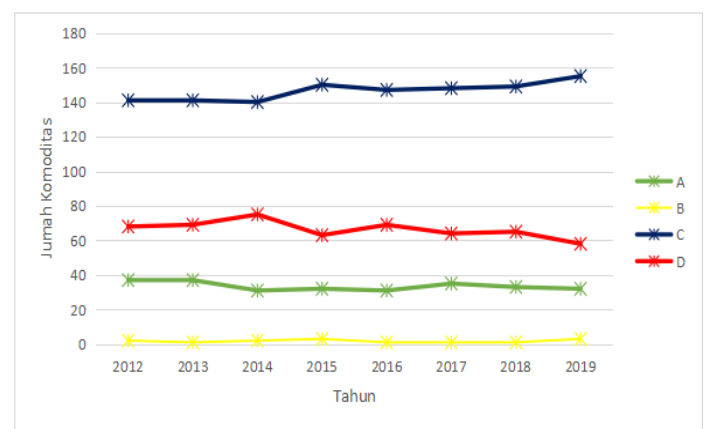

d. Indonesia - Filipina 


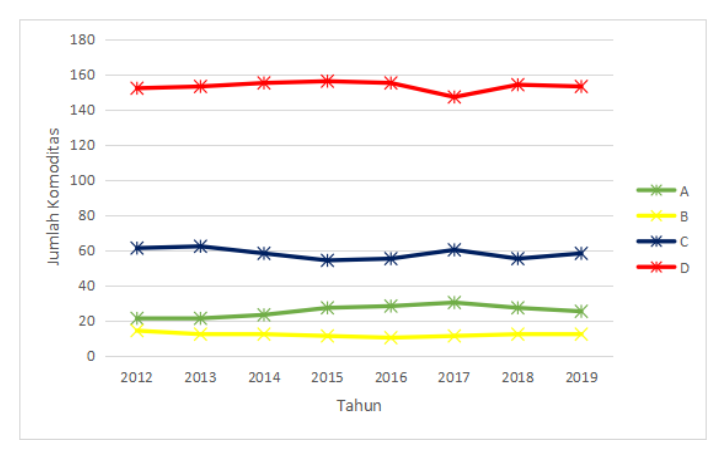

e. Indonesia - Thailand

Sumber : UN Comtrade, diolah

Rata-rata jumlah komoditas (HS 4 digit) di kelompok $\mathrm{A}, \mathrm{B}, \mathrm{C}$, dan $\mathrm{D}$ dari product mapping pada tahun 2019 ditunjukkan dalam tabel 5.1. Hal ini dilakukan untuk mengetahui kemampuan daya saing Indonesia terhadap masingmasing negara untuk setiap kategori grup pada tahun tersebut.

Tabel 5.1. Rata- rata Jumlah Komoditas di Kelompok A, B,C dan D

\begin{tabular}{|c|c|c|c|c|c|}
\hline & $\begin{array}{c}\text { Group } \\
\text { A }\end{array}$ & & & Group B & \\
\hline $\begin{array}{c}\text { Indonesia - } \\
\text { Malaysia }\end{array}$ & 22 & $8,88 \%$ & $\begin{array}{c}\text { Indonesia - } \\
\text { Malaysia }\end{array}$ & 10 & $4,03 \%$ \\
\hline $\begin{array}{c}\text { Indonesia - } \\
\text { Singapura }\end{array}$ & 14 & $5,64 \%$ & $\begin{array}{c}\text { Indonesia - } \\
\text { Singapura }\end{array}$ & 11 & $4,43 \%$ \\
\hline $\begin{array}{c}\text { Indonesia - } \\
\text { Filipina }\end{array}$ & 32 & $12,90 \%$ & $\begin{array}{c}\text { Indonesia - } \\
\text { Filipina }\end{array}$ & 3 & $1,20 \%$ \\
\hline $\begin{array}{c}\text { Indonesia - } \\
\text { Thailand }\end{array}$ & 25 & $10,08 \%$ & $\begin{array}{c}\text { Indonesia - } \\
\text { Thailand }\end{array}$ & 12 & $4,83 \%$ \\
\hline $\begin{array}{c}\text { Indonesia - } \\
\text { China }\end{array}$ & 14 & $5,64 \%$ & $\begin{array}{c}\text { Indonesia - } \\
\text { China }\end{array}$ & 11 & $4,43 \%$ \\
\hline Rata- rata & 21.4 & $8.62 \%$ & Rata- rata & 9,4 & $3,18 \%$ \\
\hline C & 45 & $18,14 \%$ & $\begin{array}{c}\text { Indonesia - } \\
\text { Malaysia }\end{array}$ & 171 & $\begin{array}{c}68,95 \\
\%\end{array}$ \\
\hline $\begin{array}{c}\text { Indonesia - } \\
\text { Malaysia }\end{array}$ & 50 & $20,20 \%$ & $\begin{array}{c}\text { Indonesia - } \\
\text { Singapura }\end{array}$ & 173 & 69,75 \\
\hline $\begin{array}{c}\text { Indonesia - } \\
\text { Singapura }\end{array}$ & 155 & $62,5 \%$ & $\begin{array}{c}\text { Indonesia - } \\
\text { Filipina }\end{array}$ & 58 & $\begin{array}{c}23,38 \\
\%\end{array}$ \\
\hline $\begin{array}{c}\text { Indonesia - } \\
\text { Filipina }\end{array}$ & $23,40 \%$ & $\begin{array}{c}\text { Indonesia - } \\
\text { Thailand }\end{array}$ & 153 & 61,69 \\
$\%$
\end{tabular}

Sumber : Uncomtrade, data diolah

Pada tahun 2019 sekitar 58,68 persen komoditas industri pertahanan Indonesia berada pada kategori D (tidak berspesialisasi pada ekspor dan tidak memiliki keunggulan komparatif. Kategori dengan jumlah komoditas terbesar kedua berada pada kelompok C sebesar 28,88 persen (berspesialisasi ekspor namun belum memiliki keunggulan komparatif) selanjutnya komoditas pada kelompok A (berspesialisasi ekspor dan memiliki keunggulan komparatif) memiliki nilai ratarata sebesar 8,62 persen dan yang terakhir kategori pada kelompok B (memiliki keunggulan komparatif namun tidak berspesialisasi ekspor) memiliki nilai ratarata sebesar 3,18 persen. Dominasi Grup D dan C (bersama-sama sekitar 87,56 persen dalam jumlah produk) menunjukkan bahwa produk industri pertahanan indonesia terhadap negara ASEAN 4 dan China tidak memiliki keunggulan komparatif namun kemungkinan berperan sebagai negara net exporter.

Tabel 5.2. menyajikan pemetaan produk untuk perdagangan Indonesia dengan ASEAN-4 dan China pada tahun 2019. Kolom kedua mewakili sepuluh besar produk yang terdaftar pada kategori A untuk setiap kegiatan perdagangan. Produk-produk ini dianggap sebagai sepuluh produk terbaik dalam keunggulan komparatif dan memiliki neraca perdagangan yang positif (neteksportir). Seperti yang dapat kita lihat di atas, komoditas ekspor dan keunggulan komparatif Indonesia sebagian besar berasal dari produk-produk primer, produk-produk ini biasanya nanti akan diolah kembali menjadi produk jadi oleh negara pengimpor. Beberapa produk yang memiliki keunggulan lebih di satu negara diantaranya adalah sel primer dan batere primer serta bahan listrik (8506), mesin piston pembakaran internal roter atau spark-ignition (8407), Mesin penjual barang otomatis (perangko, makanan atau minuman) termasuk mesin penukar uang ( 8476), dan yang terakhir Tabung, pipa dan profil berongga dari besi cor (7303). 


\section{Tabel 5.2. Product Mapping Industri Pertahanan Indonesia Terhadap ASEAN 4 dan China Tahun 2019 Products Mapping Indonesia - Malaysia}

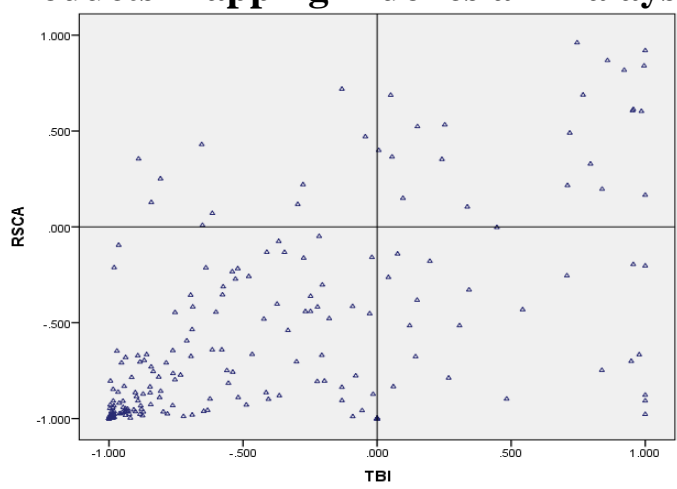

\begin{tabular}{|c|c|}
\hline & Top Ten Products (2019) \\
\hline 1. & Indonesia - Malaysia \\
\hline$H S$ & Commodity Description \\
\hline 7403 & $\begin{array}{l}\text { Copper, refined, and copper alloys, unwrought } \\
\text { (excluding copper alloys of heading } 7405 \text { ) }\end{array}$ \\
\hline 7219 & $\begin{array}{l}\text { Flat-rolled products of stainless steel, of a width of } \\
>=600 \mathrm{~mm} \text {, hot-rolled or cold-rolled }\end{array}$ \\
\hline 7408 & $\begin{array}{l}\text { Copper wire (excluding surgical sutures, stranded } \\
\text { wire, cables, plaited bands and the like }\end{array}$ \\
\hline 7208 & $\begin{array}{l}\text { Flat-rolled products of iron or non-alloy steel, of a } \\
\text { width }>=600 \mathrm{~mm} \text {, hot-rolled, not clad }\end{array}$ \\
\hline 8407 & $\begin{array}{l}\text { Spark-ignition reciprocating or rotary internal } \\
\text { combustion piston engine }\end{array}$ \\
\hline 8506 & $\begin{array}{l}\text { Primary cells and primary batteries, electrical; par } \\
\text { thereof (excluding spent) }\end{array}$ \\
\hline 7406 & $\begin{array}{l}\text { Powders and flakes, of copper (excluding grains of } \\
\text { copper and spangles of heading } 8308 \text { ) }\end{array}$ \\
\hline 8429 & $\begin{array}{l}\text { Self-propelled bulldozers, angledozers, graders, } \\
\text { levellers, scrapers, mechanical shovels, excavators, }\end{array}$ \\
\hline 8476 & $\begin{array}{l}\text { Automatic goods-vending machines, e.g. postag } \\
\text { stamp, cigarette, food or beverage machines }\end{array}$ \\
\hline 7303 & Tubes, pipes and hollow profiles, of cast iron \\
\hline
\end{tabular}

\section{Products Mapping Indonesia - Singapura}

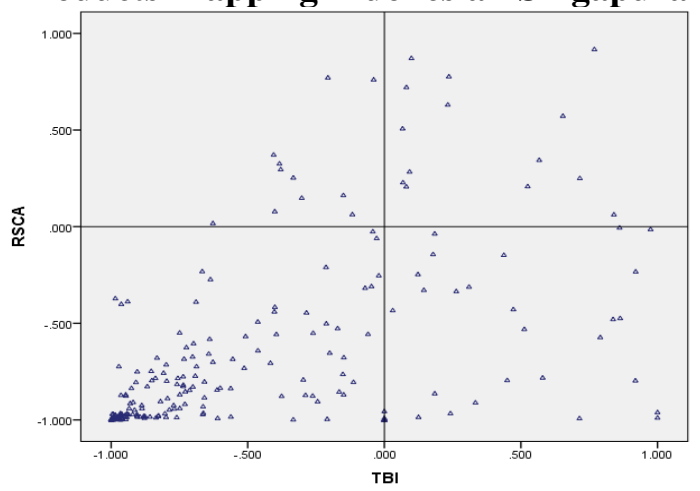

Top Ten Products (2019)

2. Indonesia - Singapura

HS Commodity Description

8522 Parts and accessories suitable for use solely or principally with sound reproducing and recording

8506 Primary cells and primary batteries, electrical; parts thereof (excluding spent)

8532 Electrical capacitors, fixed, variable or adjustable "preset"

8423 Weighing machinery, incl. weight-operated counting or checking machines
8482 Ball or roller bearings (excluding steel balls of heading 7326); parts thereof

8468 Machinery and apparatus for soldering, brazing or welding

7311 Containers of iron or steel, for compressed or liquefied gas 8907 Rafts, tanks, coffer-dams, landing stages, buoys, beacons and other floating structures

8905 Light-vessels, fire-floats, dredgers, floating cranes, and other

8473 Parts and accessories (other than covers, carrying cases and the like)

Products Mapping Indonesia - Thailand

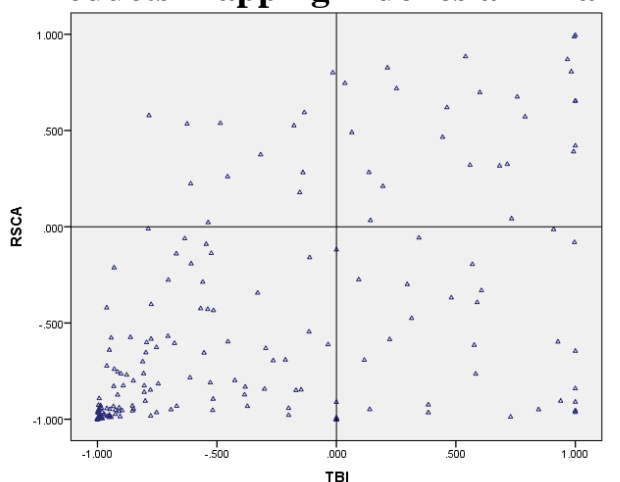

Top Ten Products (2019)

3. Indonesia - Thailand

HS Commodity Description

7206 Iron and non-alloy steel in ingots or other primary forms

7218 Stainless steel in ingots or other primary forms

8476 Automatic goods-vending machines, e.g. postage stamp, cigarette, food or beverage machines

7614 Stranded wire, cables, plaited bands and the like, of aluminium

7312 Stranded wire, ropes, cables, plaited bands, slings and the like, of iron or steel

8409 Parts suitable for use solely or principally with internal combustion piston engine

7313 Barbed wire of iron or steel; twisted hoop or single flat wire

7207 Semi-finished products of iron or non-alloy steel

8528 Monitors and projectors, not incorporating television reception apparatus

7304 Tubes, pipes and hollow profiles, seamless, of iron or steel

\section{Products Mapping Indonesia - Filipina}

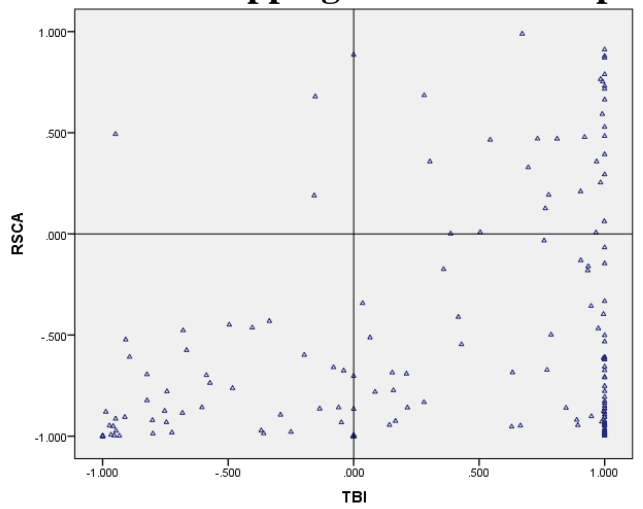

\section{Top Ten Products (2019)}

4. Indonesia - Filipina

HS Commodity Description

8407 Spark-ignition reciprocating or rotary internal combustion piston engine

7407 Bars, rods and profiles, of copper, n.e.s 
8478 Machinery for preparing or making up tobacco, not specified or included elsewhere

8506 Primary cells and primary batteries, electrical; parts thereof

7605 Aluminium wire (excluding stranded wire, cables

7312 Stranded wire, ropes, cables, plaited bands, slings and the like

7313 Barbed wire of iron or steel; twisted hoop or single flat wire,

7320 Springs and leaves for springs, of iron or steel

8505 Electromagnets (excluding magnets for medical use); permanent magnets

8408 Compression-ignition internal combustion piston engine

Products Mapping Indonesia - China

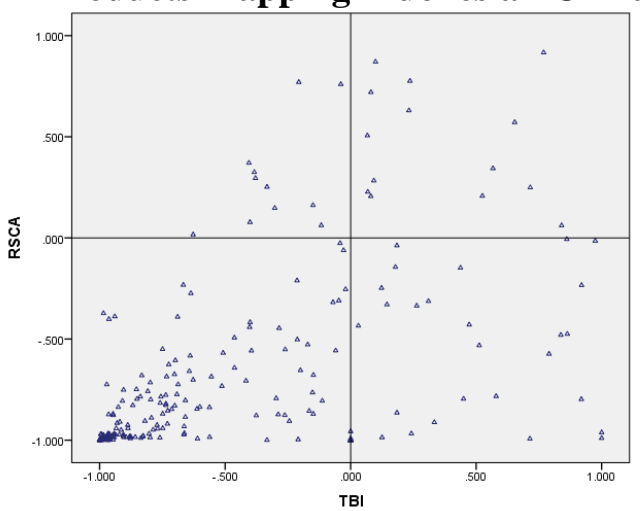

Top Ten Products (2019)

5. Indonesia - China

HS Commodity Description

8522 Parts and accessories suitable for use solely or principally with sound reproducing and recording

8506 Primary cells and primary batteries, electrical; parts thereof

8532 Electrical capacitors, fixed, variable or adjustable "pre-set"; parts thereof

8423 Weighing machinery, incl. weight-operated counting or checking machines

Ball or roller bearing

8468 Machinery and apparatus for soldering, brazing or welding, whether or not capable of cutting

7311 Containers of iron or steel, for compressed or liquefied ga

8905 Light-vessels, fire-floats, dredgers, floating cranes, and other vessels the navigability

8473 Parts and accessories (other than covers, carrying cases and the like) suitable for use solely

8907 Rafts, tanks, coffer-dams, landing stages, buoys, beacons and other floating structures

Source : UN Comtrade, diolah

\section{KESIMPULAN}

Makalah ini menganalisis keunggulan komparatif Industri pertahanan Indonesia terhadap negara ASEAN-4 dan China menggunakan analisis Product Mapping. Dengan menggunakan data yang diambil dari UN COMTRADE yang diakses dari situs ITC, maka dilakukan analisis terhadap 10 produk industri pertahahan indonesia yang diklasifikasikan dengan HS 4 digit sehingga terdapat 248 komoditas. Dari analisa didapatkan hasil bahwa, sebagiannbesar industri pertahanan Indonesia terhadap negara ASEAN-4 dan China masih tidak memiliki keunggulan komparatif dan tidak berspesialisasi ekspor (Kelompok D), Komoditas yang masuk ke dalam kategori A yaitu komoditas ekspor (net-eksportir) dan memiliki keunggulan komparatif dari Industri pertahanan Indonesia di lebih dari satu negara adalah sel primer dan batere primer serta bahan listrik (8506), mesin piston pembakaran internal roter atau sparkignition (8407), Mesin penjual barang otomatis (perangko, makanan atau minuman) termasuk mesin penukar uang ( 8476), Tabung, pipa dan profil berongga dari besi cor (7303).

\section{DAFTAR PUSTAKA}

Kojima, K. 2000. The "flying geese" model of Asian economics development origin,theoritical extensions, and regional policy implications. Journal of AsianEconomics, 11 (4),375-401

Laursen, K. 1998. Revealed comparative advantage and the alternatives as measures of international

specialisation (DRUID Working Paper No. 9830). Retrieved from Danish Research Unit For Industrial Dynamics $\backslash$

Kementerian Keuangan, 2020, Nota Keuangan dan Anggaran Pendapatan dan Belanja Negara Tahun Anggaran 2015-2020, Jakarta.

Ningsih, Novri Surya. 2019. Hambatan yang Dihadapi ASEAN Defense Industry Collaboration (ADIC) dalam Menentukan Platform Persenjataannya. Jurnal Hubungan Internasional. Tahun XII, No.1, Januari - Juni 2019

Raghavan, S., \& Ben-Ari, G. (2011, September 7). ASEAN Defense Industry Collaboration. CSIS Current Issues, pp. 1-2

Sanidas, E. And Shin, Y. 2010. Comparison of revealed comparative advantage indices with Application to trade 
tendencies of east asian countries.

Retrieved from

www.akes.or.kr/eng/papers(2010)

/24.full.pdf

Shohibul, A. 2013. Revealed comparative advantage measure : ASEAN-China

trade flows. Journal of Economics and Sustainable Development, 4 (7), 136-145

Widodo, T. 2009. Comparative advantage : theory, empirical measures, and case studies.Review of Economic and Business Studies. 4, 57-82

Wijaya, Dicky Hadi. 2015. Kolaborasi Industri Pertahanan ASEAN (ADIC) Ditinjau dari Keunggulan omparatif Komoditi Indonesia Dengan 3 Negara Anggota; Malaysia, Singapura, dan Thailand. 